\title{
Plights of Medical Postgraduate Students during COVID-19 Pandemic
}

\author{
Raju Vaishya
}

Journal of Postgraduate Medicine, Education and Research (2020): 10.5005/jp-journals-10028-1399

Coronavarus disease-2019 (COVID-19) pandemic has severely disrupted the postgraduate $(\mathrm{PG})$ training and teaching. The lockdowns, along with the fear of acquiring infection among the patients and doctors, have led to significant decrease in the numbers of outpatients, inpatients, and surgical cases. All these events have resulted in a drastic reduction in the "clinical material" and have consequently affected the training and experience of the PG students. This is relevant across all medical specialties and more so in the surgical specialties.

The PG teaching has also had a significant blow, with the stoppage of conventional teaching such as lectures, clinical rounds, interdepartmental meeting, seminars, case presentations, and other academic activities. ${ }^{1}$ The interaction between the trainees and the trainers has been deprived, leading to inadequate training of the PGs, by way of lack of sharing the personal and practical experience and knowledge of the trainers with the trainees. The PGs are also facing severe problems in completing their compulsory dissertations and are not being able to attend the physical workshops and conferences to widen their knowledge and experience. The dissertations are compulsory for most PG courses and for the PGs to understand and undertake the research, which forms the foundation for many of them in the future to carry out more research and publications, which are so essential for carrying the medical science forward and helping the present and future patients with the application of the outcomes of these research. The PGs in the present crisis are unable to do full justice to their theses work due to lack of patient load required for their clinical research topic, lack of supervision by their guide and other distractions like mental stress and other clinical work (like COVID-19 duties).

The PG courses are aimed to create professionals who are able to deliver specialized and evidence-based quality health care in their sphere of specialty. Since the impact of this pandemic, most of the trainees would lose a significant amount of their stipulated tenure of their PG course (1/3rd to $1 / 2)$, leading to inadequate training, practical experience, and inability to do a good quality research related to their dissertations. The PG training in India inherently has several limitations and challenges attached to it, as the teaching and training is so variable across various institutes, and many of these may not be able to provide comprehensive training, enough to make sound specialists at the end of the PG course, and this pandemic has further compounded these problems. Therefore, these COVID-19-affected PGs are likely to be inadequately trained and shall not be able to provide skillful and sound treatment confidently to their patients after clearing the exit exams. ${ }^{2}$

The pandemic has forced the PGs to avoid "face-to-face" interactions and the social distancing with the patients, colleagues, and the teachers, leading to severe impact on their clinical teaching. ${ }^{3}$ To counter the difficulties posed by the pandemic, virtual teaching and learning has gained recent popularity. The clinical examination, invasive, and surgical procedures cannot be learnt

Department of Orthopaedics and Joint Replacement Surgery, Indraprastha Apollo Hospitals, New Delhi, India

Corresponding Author: Raju Vaishya, Department of Orthopaedics and Joint Replacement Surgery, Indraprastha Apollo Hospitals, New Delhi, India, Phone: +91 9810123331, e-mail: raju.vaishya@gmail.com

How to cite this article: Vaishya R. Plights of Medical Postgraduate Students during COVID-19 Pandemic. J Postgrad Med Edu Res 2020;54(3):158-159.

Source of support: Nil

Conflict of interest: None

so well by virtual means and need to be practiced physically and repeatedly under supervision. Hence, the didactic means of teaching and training cannot be replaced adequately by virtual training and learning, as the quality of this type of learning may be variable and is governed by several factors such as the interest, commitment, and concentration of students; expertise of the teacher in virtual training; and the type of software used. Several remote learning platforms are now available, using the telemedicine and tele-health, to deliver education and training in the present times. The remote learning techniques are cost-effective and easier to adopt and apply than the conventional teaching; these suffer from several disadvantages and shortcomings, mainly as it requires a sincere engagement and participation of both the trainees and the trainers in the teaching/training and discussions. ${ }^{4}$

Surgical simulation is a useful tool for teaching surgical and invasive techniques; however, due to its prohibitive cost, it may not be universally affordable and available. ${ }^{5,6}$ These techniques are likely to develop even more and are likely to become acceptable to both the trainees and the teachers and may be integrated in future academic curriculum after the COVID-19 era.

Apart from lack of training in their specialty, the PGs are posted for COVID-19 duties, leading to mental stress and high chances of acquiring the viral infection. The Government and Teaching organizations should consider the plights of PGs and formulate satisfactory solutions to meet the challenges raised by this pandemic for these trainees.

\section{References}

1. Lal H, Sharma DK, Patralekh MK, et al. Outpatient department practices in orthopaedics amidst COVID-19: the evolving model. J ClinOrthop Trauma. 2020;11(4):700-712. DOI: 10.1016/j.jcot.2020.05.009.

2. Dougherty PJ, Jain AK. Orthopaedic surgery education in India. Clin Orthop Relat Res 2014;472(2):410-414. DOI: 10.1007/s11999-0133391-y.

o The Author(s). 2020 Open Access This article is distributed under the terms of the Creative Commons Attribution 4.0 International License (https://creativecommons. org/licenses/by-nc/4.0/), which permits unrestricted use, distribution, and non-commercial reproduction in any medium, provided you give appropriate credit to the original author(s) and the source, provide a link to the Creative Commons license, and indicate if changes were made. The Creative Commons Public Domain Dedication waiver (http://creativecommons.org/publicdomain/zero/1.0/) applies to the data made available in this article, unless otherwise stated. 
3. Kumar S, Tuli SM. Orthopedic education: Indian perspective. Indian J Orthop 2008;42(3):245-246. DOI: 10.4103/0019-5413.41848.

4. Palan J, Roberts V, Bloch B, et al. The use of a virtual learning environment in promoting virtual journal clubs and casebased discussions in trauma and orthopaedic postgraduate medical education: the leicester experience. J Bone Joint Surg $\mathrm{Br}$ 2012;94(9):1170-1175. DOI: 10.1302/0301-620X.94B9.28780.
5. Gomoll AH, O'Toole RV, Czarnecki J, et al. Surgical experience correlates with performance on a virtual reality simulator for shoulder arthroscopy. Am J Sports Med 2007;35(6):883-888. DOI: 10.1177/0363546506296521.

6. lyengar KP, Jain VK, Vaish A, et al. Post COVID-19: Planning strategies to resume orthopaedic surgery-challenges and considerations.J Clin Orthop Trauma 2020;11:S291-S295. DOI: 10.1016/j.jcot.2020.04.028. 